\title{
Occurrence and genetic characterization of Listeria spp. in minimally processed vegetables commercialized in Porto Alegre, Brazil*
}

\author{
Sylvia Elisa Frizzo Verdin ${ }^{1}$, Silvia Regina Pavan da Silva ${ }^{1}$, \\ Dariane Castro Pereira ${ }^{2}$, Aline Modelski Schatkoski ${ }^{2} \&$ Gertrudes Corção
}

\begin{abstract}
Minimally processed vegetables go through many steps before they are refrigerated, selection, washing, peeling, cutting, disinfection and finally packaging. However, if no care is taken at the origin of the raw materials and in the processing stages, there is a chance of finding pathogenic bacteria, such as Listeria monocytogenes, which are able to grow at low temperatures. The aim of this research was to verify the occurrence of Listeria sp. in minimally processed vegetables sold in Porto Alegre, Brazil, and the genetic relationship among the isolates. Minimally processed salads were sampled monthly from local supermarkets and analyzed by inoculation on Listeria Enrichment Broth and subsequent seeding on two selective media, Palcam and Modified Oxford Agar. The typical colonies were identified to species level and their intergenic region 16S-23S rDNA were amplified in order to verify the genetic variability. Species of Listeria were found in 23 of the 52 processed salad samples analyzed and L. monocytogenes was found in seven. The presence of L. monocytogenes in the samples is a health concern, as these salads are eaten without further treatment by the consumer. The amplification of the intergenic region 16S-23S rDNA, showed a great genetic diversity among the isolates, with 43 different patterns, proving the usefulness of this technique in epidemiologic studies.
\end{abstract}

Key words: Listeria, minimally processed, vegetables, 16S-23S rDNAS, spacer region.

\section{RESUMO}

Hortaliças minimamente processadas passam por etapas como: lavagem, seleção, descasque, corte, sanificação e, depois de embaladas, são armazenadas sob refrigeração. Todavia, se cuidados sobre a origem do produto bruto ou durante as fases de processamento não são respeitados, existe a possibilidade de se encontrar bactérias patogênicas, como Listeria monocytogenes, a qual pode crescer em temperaturas baixas. Este trabalho teve por objetivo verificar a ocorrência de Listeria sp. em hortaliças folhosas minimamente processadas comercializadas em Porto Alegre - RS e verificar a relação genética entre os isolados. Saladas folhosas minimamente processadas foram coletadas mensalmente em supermercados locais, semeadas em caldo de enriquecimento para Listeria e subsequentemente em dois meios seletivos, ágar PALCAM e ágar Oxford Modificado. Foi realizado isolamento e identificação das espécies das colônias características e a amplificação da região intergênica 16S23S do rDNA para verificar a variabilidade genética. Espécies de Listeria foram encontradas em 23 das 52 amostras de saladas processadas analisadas, sendo L. monocytogenes encontrada em sete amostras. A presença de L. monocytogenes é preocupante, pois estes produtos são consumidos sem nenhum tratamento pelo consumidor. Através da amplificação da região intergênica 16S-23S do rDNA de Listeria sp. observou-se grande diversidade entre os isolados, gerando 43 padrões, comprovando a utilidade desta técnica em estudos epidemiológicos.

Descritores: Listeria, minimamente processados, vegetais, 16S-23S rDNA, região espaçadora. 


\section{INTRODUCTION}

The increasing demand for fresh fruit and vegetables, has encouraged the consumption of minimally processed foods [22,23]. However, if these ready-to-eat food products meet the claims for practicality of modern society, they may also represent hazard to consumers, once they do not systematically carry out any sanitization process before such products are eaten. When present in minimally processed vegetables, Listeria isolates may be able to survive if no inhibition mechanism is prompted during storage [12], since this bacteria grows at ordinary refrigeration temperatures and in modified atmosphere [5,21]. Since these readyto-eat products are quite popular, the investigation of the occurrence of $L$. monocytogenes in leafy vegetables, especially of the kind used in salad preparations, is particularly important.

The contamination of vegetables may be of diverse sources and take place at different stages of a food processing plant. It may take place in the processing environment as a whole [8,17], either before or even after the food has been sanitized $[10,20]$. In this scenario, molecular methods have proved themselves useful in the establishment of contamination sources throughout a production line $[13,14,18,19]$. With this intent, the amplification of the $16 \mathrm{~S}-23 \mathrm{~S}$ rDNA spacer regions, whether cleaved or not with restriction enzymes, has been used in many studies $[1,3,6,26]$.

This study aimed (i) to establish the occurrence of Listeria sp. in minimally processed leafy vegetables, (ii) to characterize the isolates by amplification of the $16 \mathrm{~S}$ - 23S rDNA spacer regions., and (iii) to correlate the data obtained with the origin of the product.

\section{MATERIALS AND METHODS}

Ready-to-eat salad samples were randomly collected in supermarkets of Porto Alegre (RS, Brazil) from August 2004 to August 2005. Four samples were collected per month, totaling 52 samples that varied for salad mix types and commercially available brands (A, B and C). Each sample was composed by three $200 \mathrm{~g}$ salad packages of the same brand and salad mix, to make up a $600 \mathrm{~g}$ analysis unit. Twenty-five grams of each sample were homogenized in $225 \mathrm{~mL}$ Listeria enrichment broth (LEB) and incubated at $30^{\circ} \mathrm{C}$ for 48 hours, the agar plates were inspected for typical colonies for the following 7 days. Afterwards, Listeria colonies were isolated from Modified Oxford Agar (MOX) and Palcam agar (PAL) and seeded in Triptone
Soy Agar supplemented with yeast extract (TSA - YE $0.6 \%$ ) for purification. The following biochemical assays were used to establish genus and identify species: Gram test; catalase; specific motility at $28^{\circ} \mathrm{C}$; Triple-Sugar-Iron; methyl red; Voges-Proskauer; nitrate reduction; fermentation of xylose, rhamnose, and manitol; hemolysis and CAMP-test.

Chromosomal DNA was extracted [4] and the amplification of the 16S - 23S rDNA spacer region was carried out using primers designed based on the sequences for different Listeria sp. found in GenBank: 16S LisF 5' GCTGGATCACCTCCTTTCTA 3', and 23S LisR 5' GCGCCCTTYCTAACYTAACC 3'. The reactions were carried out in $10 \mathrm{mM}$ Tris/ $\mathrm{HCl}, \mathrm{pH} 8.3$; $50 \mathrm{mM} \mathrm{KCl} ; 2 \mathrm{mM} \mathrm{MgCl}_{2} ; 0.2 \mathrm{mM}$ dNTPs; $0.38 \mu \mathrm{M}$ primer 16S LisF; $0.5 \mu \mathrm{M}$ primer 23S LisR; $1 \mathrm{U}$ Taq DNA polymerase and $100 \mathrm{ng}$ of template DNA, to a final volume of $25 \mu \mathrm{L}$. Amplification reactions were conducted in a thermal-cycler (Mastercycler Personal Eppendorf) as follows: an initial denaturation step at $94^{\circ} \mathrm{C}$ for $2 \mathrm{~min}$ followed by 30 cycles at $94^{\circ} \mathrm{C}$ for 1 min, at $53^{\circ} \mathrm{C}$ for $1 \mathrm{~min}$, at $72^{\circ} \mathrm{C}$ for $1 \mathrm{~min}$, and a final extension step at $72^{\circ} \mathrm{C}$ for $10 \mathrm{~min}$. For each set of PCR analyses, positive controls were prepared with $L$. monocytogenes ATCC 15315 and L. innocua ATCC 33090, these reference strains behaved unvaryingly throughout the experiments. The PCR products were electrophoresed in $8 \%$ polyacrylamide gels $(10 \mathrm{~V} / \mathrm{cm}$ for $2 \mathrm{~h}$ $30 \mathrm{~min}$.) stained with ethidium bromide $(0.5 \mu \mathrm{g} / \mathrm{mL})$, analyzed under UV light and photographed with a digital camera Kodak 1D (version 3.5.2). The molecular marker $\lambda$ EcoRI / HindIII / ClaI was used as a standard for inspecting fragment size.

\section{RESULTS}

In the samples analyzed in the present study Listeria species were isolated in 23 of the 52 samples of minimally processed salad products analyzed. As for the commercial brands chosen, Listeria sp. were detected in 16 samples of brand $\mathrm{A}(\mathrm{n}=24), 5$ samples of brand $B(n=10)$, and in 2 samples of brand $C(n=18)$. L. seeligeri was detected in 11 samples, L. monocytogenes in 7, L. welshimeri in 7, L. grayi in 6, L. innocua in 4 , and L. ivanovii in 3 samples. No correlation between the presence of Listeria species and the composition of the salad mixes was observed. (Table 1). The highest occurrence of Listeria was between January and April 2005, when Listeria were isolated in 3 samples per collection. The most common species 
throughout the year were L. seeligeri and L. welshimeri, detected in almost all brands analyzed. L. seeligeri prevailed in the samples as a whole, whereas L. monocytogenes prevailed in warm weather samples.

At the molecular analysis, 160 strains of the 175 Listeria isolates were characterized, since 15 strains did not recover for DNA extraction $(6$ L. welshmimeri, 3 L. innocua, 2 L. ivanovii, 2 L. seeligeri, 1 L. monocytogenes, and 1 L. grayi subspecies grayi). A total of 43 different patterns with 15 fragments were observed. The most frequent pattern was pattern 41 , detected in 33 isolates (Table 1). L. monocytogenes and L. seeligeri presented the highest number of patterns in common, patterns 18, 35, and 38. Fourteen patterns were found in more than one species, and 7 patterns were detected in one species exclusively. As for the commercial brands chosen for investigation, more specifically, Brands A and B shared different patterns for L. grayi (pattern 13) and L. seeligeri (patterns 18, 24, 35, and 39). Brands $A$ and $C$ shared pattern 35 for L. monocytogenes, whereas Brands B and $\mathrm{C}$ did not share any patterns. Recurring strains were observed, as follows: L. monocytogenes pattern 29, detected in brand $\mathrm{A}$ at different summer collections; L. seeligeri pattern 41, identified in brand $\mathrm{A}$ in (autumn and winter 2004 and 2005); L. seeligeri pattern 23, detected in brand $\mathrm{A}$ at different winter collections; L. seeligeri pattern 24, detected in brand A in winter 2004 and 2005 and in brand $\mathrm{B}$ in spring; L. seeligeri pattern 18 , detected in brand $\mathrm{B}$ in spring, and in brand $\mathrm{A}$ in autumn and winter; L. seeligeri pattern 39, detected in brand B in spring, and in brand A in winter. These last 3 strains recurred in samples of identical origin (Table 1). The pattern found for the isolate L. grayi subspecies murrayi was the same as observed for the 15 isolates of L. grayi subspecies grayi (pattern 28).

\begin{tabular}{|c|c|c|c|c|c|c|c|c|c|c|}
\hline \multirow{2}{*}{$\begin{array}{l}\text { Sampling } \\
\text { month }\end{array}$} & \multirow{2}{*}{$\begin{array}{l}\text { Brand of } \\
\text { salad mix } \\
\text { analysed }{ }^{\#}\end{array}$} & \multirow{2}{*}{$\begin{array}{l}\text { 16S-23S rDNA } \\
\text { intergenic region } \\
\text { pattern observed }\end{array}$} & \multicolumn{8}{|c|}{ No. of isolates for each brand and salad mix } \\
\hline & & & $\begin{array}{c}L . \\
\text { monocytogenes }\end{array}$ & L. innocua & L. seeligeri & L. welshimeri & L. ivanovii & $\begin{array}{c}\text { L. grayi } \\
\text { subsp. grayi }\end{array}$ & $\begin{array}{c}\text { L. grayi } \\
\text { subsp. murrayi }\end{array}$ & Listeria sp. \\
\hline \multirow{2}{*}{ August 2004} & $A 1^{* *}$ & $24,29,41$ & - & - & 3 & $1^{*}$ & - & - & - & - \\
\hline & A2 & $16,27,13$ & 3 & - & - & - & - & 1 & - & - \\
\hline October 2004 & $B 1^{* *}$ & $16,13,28$ & - & - & 1 & $1^{*}$ & - & $18\left(1^{*}\right)$ & - & - \\
\hline November 2004 & B2 & $\begin{array}{l}4,6,9,18,19,24 \\
30,34,35,39,9\end{array}$ & - & - & 13 & - & - & 1 & - & - \\
\hline \multirow[b]{2}{*}{ December 2004} & $\mathrm{~A} 1$ & 29 & - & - & - & $2^{*}$ & - & 1 & - & - \\
\hline & A3 & $\begin{array}{r}1,5,11,14 \\
15,37,29,28 \\
\end{array}$ & - & 3 & 1 & $3\left(1^{*}\right)$ & - & 4 & 1 & - \\
\hline \multirow{3}{*}{ January 2005} & $\mathrm{~A} 1$ & 29 & 1 & - & - & - & - & - & - & - \\
\hline & A2 & & - & $1^{*}$ & - & - & - & - & - & - \\
\hline & $\mathrm{C} 1^{* *}$ & 1 & - & - & $1^{*}$ & - & - & 1 & - & - \\
\hline \multirow{3}{*}{ February 2005} & $\mathrm{~A} 1$ & 17 & - & 1 & - & - & - & - & - & - \\
\hline & A2 & $29,33,35$ & $4\left(1^{*}\right)$ & $2^{*}$ & - & - & - & - & - & - \\
\hline & B1 & 8 & - & - & - & - & 1 & - & - & - \\
\hline \multirow{3}{*}{ March 2005} & A2 & $31,41,9$ & - & - & 2 & - & 1 & - & - & - \\
\hline & B1 & 37 & 1 & - & - & - & - & - & - & - \\
\hline & B3 & 28 & - & - & - & 1 & - & - & - & - \\
\hline \multirow{3}{*}{ April 2005} & $\mathrm{~A} 2$ & $2,18,32$ & 3 & - & - & - & - & - & - & - \\
\hline & A3 & $\begin{array}{c}38,3,10,18,20 \\
22,23,25,37 \\
38,41,43\end{array}$ & 2 & - & 19 & - & - & - & - & - \\
\hline & $\mathrm{C} 1^{* *}$ & $21,35,36,41,42$ & 6 & - & - & - & - & - & - & - \\
\hline May 2005 & $\mathrm{~A} 1$ & - & - & - & $1^{*}$ & - & - & - & - & - \\
\hline June 2005 & A3 & $\begin{array}{c}7,17,18,23,26 \\
35,39,41,26\end{array}$ & - & - & 38 & 1 & - & - & - & - \\
\hline \multirow{2}{*}{ July 2005} & $\mathrm{~A} 1$ & $23,24,39,40,41$ & - & - & 5 & $1^{*}$ & - & - & - & 1 \\
\hline & A3 & $39,40,41$ & - & - & 6 & - & - & - & - & - \\
\hline August 2005 & $\mathrm{~A} 2$ & $5,12,23$ & - & - & - & - & $18\left(2^{*}\right)$ & - & - & - \\
\hline Total of samples & & 23 & 7 & 4 & 11 & 7 & 3 & 6 & 1 & 1 \\
\hline Total of isolates & & & 20 & 7 & 90 & 10 & 20 & 26 & 1 & 1 \\
\hline
\end{tabular}




\section{DISCUSSION}

In vegetables, the occurrence of Listeria genus varies greatly in product range, especially in readyto-eat foods $[7,9,16,26]$. The genus Listeria can be found in different environments and L. monocytogenes is the species most associated with food borne diseases. However, the presence of other Listeria species indicates that environmental conditions are ideal to microbial growth. The presence of L. monocytogenes in ready-to-eat produce raises health concerns, as these food products are extensively consumed without further treatment. The amplification of the $16 \mathrm{~S}-23 \mathrm{~S}$ rDNA spacer regions in Listeria isolates has proved its genetic diversity, with the detection of 43 patterns. Such high number of patterns may occur due to the quantity of operons in the $16 \mathrm{~S}-23 \mathrm{~S}$ rDNA spacer regions present in the Listeria genome [11]. The genetic diversity among strains, as detected in the present study, may be explained by several aspects involved in the contamination route, such as the conditions of soils, manure, and of the water destined to irrigation and to washing. These aspects may vary considerably between food processing units, between farms, and even between seasons, which makes contamination difficult to track down for a specific point in the production chain.

Recurring strains were observed in the samples investigated, proving that these strains may be present in these food processing units or, at least, that they recur in the vegetable raw materials therein processed. This last hypothesis is plausible in the light of the fact that these recurring strains are detected in different commercial brands that process raw food material of identical origin. Recurring Listeria strains have also been identified by other authors $[2,15,24,27]$, who suggested that the main contamination source is ultimately the processing unit itself. Interestingly, the occurrence of the same genotypic profile in isolates of distinct origin evinces the role played by one same strain in the contamination of different products. Nevertheless, it remains to be established whether this given strain has recently been dispersed or is a common strain adapted to the food processing environment.

\section{CONCLUSIONS}

All six Listeria species were detected and isolated from the salad samples analyzed, roughly throughout the entire sampling period. These findings may reveal the degree of extensive distribution and resistance of this microorganism during the processing and storing procedures adopted for this kind of food product. Though simple, the molecular method used in the present study afforded the discrimination between isolates of the same species. The method described may be equally useful in the investigation of disease outbreaks, in the identification of contamination sources, and in the characterization of inter- and intraspecies genetic diversity. The mapping of isolate dispersal, both in food processing environments and in food items themselves, will assist the outlining of hygiene measures against Listeria sp. in the production of safe foods.

Acknowledgements. The authors thank the Conselho Nacional de Desenvolvimento Científico e Tecnológico (CNPq) and the Coordenação de Aperfeiçoamento de Pessoal de Nível Superior (CAPES) for the financial support to this study.

\section{REFERENCES}

1 Abed Y., Davin-Regli A., Bollet C. \& De Micco P. 1995. Efficient discrimination of Mycobacterium tuberculosis strains by 16S-23S spacer region-based random amplified polymorphic DNA analysis. Journal of Clinical Microbiology. 33: 14181420 .

2 Aguado V., Vitas A.I. \& Garcia-Jalón I. 2004. Characterization of Listeria monocytogenes and Listeria innocua from a vegetable processing plant by RAPD and REA. International Journal of Food Microbiology. 90: 341-347.

3 Antón A.I., Martínez-Murcia A.J. \& Rodriguez-Valera F. 1998. Sequence diversity in the 16S-23S intergenic spacer region (ISR) of the rRNA operons in representatives of Escherichia coli ECOR collection. Journal of Molecular Evolution. 47: 67-72.

4 Ausubel M.F. 1991. Short Protocols in Molecular Biology: a compendium of methods from current protocols in molecular biology. 2nd. edn. New York: J. Wiley, $265 \mathrm{p}$

5 Beuchat L.R. \& Brackett R.E. 1990. Growth of Listeria monocytogenes on lettuce as influenced by shredding, chlorine treatment, modified atmosphere packaging, temperature and time. Journal of Food Science. 55: 755-758. 
Verd in S.E.F., Silva S.R.P., Pereira D.C., Schatkoski A.M. \& Corção G. 2007. Occurrence and genetic characterization of Listeria spp. in minimally processed vegetables commercialized in Porto Alegre, Brazil. Acta Scientiae Veterinariae. 35: 167-172.

6 Clementino M.M., Filippis I., Nascimento C.R., Branquinho R., Rocha C.I. \& Martins O.B. 2001. PCR analysis of tRNA intergenic spacer, 16S-23S internal transcribed spacer, and random amplified relationships of Enterobacter cloacae strains. Journal of Clinical Microbiology 39: 3865-3870.

7 Curtis M.L. de Franceschi O. \& Castro N. 2002. Listeria monocytogenes en vegetales minimamente procesados. Archivos Latinoamericanos Nutricion. 52: 282-288.

8 De Roever C. 1998. Microbiological safety evaluations and recommendations on fresh produce. Food Control. 9: 321-347.

9 Farber J.M. \& Peterkin P.I. 1991. Listeria monocytogenes, a food-borne pathogen. Microbiology. Reviews. 55: $476-511$.

10 Francis G.A., Thomas C. \& O'Beirne D. 1999. The microbiological safety of minimally processed vegetables. International Journal of Food Science and Technology 34: 1-22.

11 Glaser P., Frangeul L., Buchrieser C., Rusniok C., Amend A., Baquero F., Berche P., Bloecker H., Brandt P., Chakraborty T., Charbit A., Chetouani F., Couvé E., Daruvar A., De Dehoux P., Domann E., Dominguez-Bernal G., Duchaud E., Durant L., Dussurget O., Entian K.-D., Fsihi H., Garcia-Del Portilho F., Garrido P., Gautier L., Goebel W., Gómez-López N., Hain T., Hauf J., Jackson D., Jones L. -M., Kaerst U., Dreft J., Kuhn M., Kunst F., Kurapkat G., Madueño E., Maitournam A., Mata Vicente J., Ng E., Nedjari H., Nordsiek G., Novella S., Pablos B. De Pérez-Diaz, J.-C., Purcell R., Remmel B., Rose M., Schlueter T., Simões N., Tierrez A., Vásquez-Boland J.-A., Voss H., Wehland J. \& Cossart P. 2001. Comparative Genomics of Listeria species. Science. 294: 849-852.

12 Gleeson E. \& O'Beirne D. 2005. Effects of process severity on survival and growth of Escherichia coli and Listeria innocua on minimally processed vegetables. Food Control. 16: 677-685.

13 Graves L.M., Hunter. S. B., Ong A. R., Schoonmaker-Bopp D., Hise K., Kornstein L., Devitt W.E., Haves P.S., Dunne E., Mead P. \& Swaminathan B. 2005. Microbiological aspects of the investigation that traced the 1998 outbreak of listeriosis in the United States to contaminated hot dogs and establishment of molecular subtyping-based surveillance for Listeria monocytogenes in the PulseNet Network. Journal of Clinical Microbiology. 43: 2350-2355.

14 Jaradat Z.W., Schutze G.E. \& Bhunia A.K. 2002. Genetic homogeneity among Listeria monocytogenes strains from infected patients and meat products from two geographic locations determined by phenotyping, ribotyping and PCR analysis of virulence genes. International. Journal of Food Microbiology. 76: 1-10.

15 Kabuki L.Y., Kuaye A.Y., Wiedmann M. \& Boor K.J. 2004. Molecular subtyping and tracking of Listeria monocytogenes in Latin-Style fresh-cheese processing plants. Journal of Dairy Science. 87: 2803-2812.

16 Kaneko K., Hayashidani H., Ohtomo Y., Kosuge J., Kato M., Takahashi K., Shiraki Y. \& Ogawa M. 1999. Bacterial contamination of ready-to-eat foods and fresh products in retail shops and food factories. Journal of Food Protection. 62 : 644-649.

17 Maistro L.C. 2001. Alface minimamente processada: Uma revisão. Revista Nutrição. 14: 219-224.

18 Martinez J., Rorvik L.-M., Brox V., Lassen J., Seppola M., Gram L. \& Fonnesbech V. 2003. Genetic variability among isolates of Listeria monocytogenes from products, clinical samples and processing environments, estimated by RAPD typing. International Journal of Food Microbiology. 84: 285-297.

19 Norton D. M., Mccamey M. A., Gall K. L., Scarlett J. M., Boor K. J. \& Wiedmann M. 2001. Molecular studies on the ecology of Listeria monocytogenes in the smoked fish processing industry. Applied Environmental Microbiology. 67: 198-205.

20 Nguz K., Shindano J., Samapundo S. \& Huyghebaert A. 2005.Microbiological evaluation of fresh-cut organic vegetables produced in Zambia. Food Control. 16: 623-628.

21 Rocourt J. 1996. Risk factors for listeriosis. Food Control. 7: 195-202.

22 Rosa O.O. \& Carvalho E.P. 2000. Características microbiológicas de frutos e hortaliças minimamente processados. Boletim da Sociedade Brasileira de Ciência Tecnologia dos Alimentos. 34: 84-92.

23 Sarantópoulos C.I.G.L., Alves R.M.V., Oliveira L.M. \& Gomes T.C. 1996. Princípios da tecnologia de acondicionamento em embalagens com atmosfera modificada. In: Embalagens com atmosfera modificada. Campinas: CETEA, pp:1-17. 
24 Senczek D., Stephan R. \& Untermann F. 2000. Pulsed-field gel electrophoresis (PFGE) typing of Listeria strains isolated from a meat processing plant over a 2-year period. International Journal of Food Microbiology. 62:155-159.

25 Thunbterg R.L., Tran T.T., Bennett R.W., Matthews R.N. \& Belay N. 2002. Microbial evaluation of selected fresh produce obtained at retail markets. Journal of Food Protection. 65: 677-682.

26 Toth I.K., Avrova A.O. \& Hyman L.J. 2001. Rapid identification and diferentiation of the soft rot Erwinia by 16S-23S intergenic transcribed spacer - PCR and restriction fragment length polymorphism analyses. Applied Environmental Microbiology. 67: 4070-4076.

27 Waak E., Tham W. \& Danielsson-Tham M.-L. 2002. Prevalence and fingerprinting of Listeria monocytogenes strains and in dairy plant receiving tanks. Applied and Environmental Microbiology. 68: 3366-3370. 